\title{
Debris Flow Generation Based on Critical Discharge: A Case Study of Xiongmao Catchment, Southwestern China
}

\author{
Lingfeng Gong, Chuan Tang *, Jiang Xiong and Ning Li
}

State Key Laboratory of Geohazard Prevention and Geoenvironment Protection, Chengdu University of Technology, Chengdu 610059, China; gonglingfeng2010@gmail.com (L.G.); xiongj903@gmail.com (J.X.); cdutln617@gmail.com (N.L.)

* Correspondence: tangc@cdut.edu.cn; Tel.: +86-28-8407-8948

Received: 31 December 2019; Accepted: 11 February 2020; Published: 15 February 2020

\begin{abstract}
Generation of debris flows is related to poorly sorted mixtures of soil, catchment topography, and rainfall characteristics. Runoff in a valley resulting from intensive rainfall can induce sediment movement within stream beds or along adjacent banks. The water flow in channels is affected by rainfall parameters such as duration, intensity, cumulative rainfall, etc., and is the key factor in debris movement. In this paper, the rainfall characteristics and occurrence conditions of debris flow in Xiongmao Gully on 26 July 2016 were explored. Using data from field surveys and indoor simulation experiments, evaluations of critical discharge parameters for debris movement were performed. Furthermore, debris distribution and the critical discharge characteristics were analyzed via investigation of the catchment topography and cause of the debris flow, and analysis was made of the critical discharge parameters initiating channel debris movement. A K-value clustering analysis method was applied to characterize the rainfall pattern of the study area and its effects on calculation of debris flow. The results showed that for the debris flow in Xiongmao Gully, the debris initiation in the middle reaches of the gully provided the majority of solid particles for the disaster on 26 July 2016, and the upstream confluent provided catchment. Based on the relationship determined by laboratory tests, the calculated critical discharge was $43.8 \mathrm{~m}^{3} / \mathrm{s}$, less than the peak discharge $\left(Q_{c}=66.7 \mathrm{~m}^{3} / \mathrm{s}\right)$ calculated by morphological method. In addition, it was indicated that the dominant rainfall patterns of the studied area were first-quartile and second-quartile, i.e., the rainfall occurred primarily at the early or middle stage of this rainfall event. The critical discharge for the debris flow on 26 July was achieved at $5 \%$ rainfall frequency, and the larger runoff volume was generated from a short heavy rainfall. According to specific catchment characteristics, such as distributed hydrological analysis, critical discharge, and rainfall pattern of debris flow, forewarning of a damaging debris flow could be made more effective.
\end{abstract}

Keywords: debris flow initiation; critical discharge; rainfall patterns; distributed hydrological

\section{Introduction}

Debris flows in southwestern China are sometimes initiated when soil is mobilized by a high enough water flow. Methods used to study debris flow initiation include field observation [1-3], laboratory flume experiments [4-6], statistical methods, and theoretical derivation [7-9]. Debris flow occurs frequently in catchments which have well-developed main channels and tributary gullies. The evolution of debris flows after an earthquake often occurs with increased coarse material and higher frictional resistance, which decreases their frequency and increases difficulty in debris flow identification or prediction. According to the characteristics of debris flows, Tang et al. (2008) [10] 
pointed out that the critical precipitation and initial discharge can be used as indicators for the initiation of debris flows. The discharge per unit width $\left(\mathrm{m}^{3} / \mathrm{s} \cdot \mathrm{m}\right)$ was taken as the available indicator of debris flow initiation $[2,7,9]$, due to the fact that the discharge, in combination with parameters such as debris grain size, slope angle, and sediment concentration, can be obtained and applied to scientific research, prediction, and practice.

Some flume experiment simulations of runoff discharge have been performed [6] to understand impact of gully bed gradient and average particle size. Coe et al. (2008) [2] verified the accuracy of the critical discharge of overland runoff based on field observation data. However, their results were obviously different from the source of the Wenchuan earthquake area; deposit heterogeneity should be considered when critical debris flow discharge data are computed. The same average grain size or percentage of particles less than $10 \mathrm{~mm}$ in diameter in the flume test had an influence on Wenchuan earthquake area. Severe erosion and transport led to high solid concentrations, generating debris flows. [11]. The critical discharge can be simulated in serial tests and calculated in terms of its relationships, avoiding analyzing hydrodynamic force by using the size and slope. The parameter of critical discharge could be an effective criterion to assess channel sediment instability.

According to the distributed hydrological models such as the Hydrologic Engineering Center's Hydrologic Modeling System (HEC-HMS) [12] and the Integrated Hydrologic Model (inHM) [13], the surface or subsurface hydrologic responses can be simulated. With the surface runoff discharge, two methods, (1) Manning's formula [14-16] or (2) Shen's method [17], can be used to calculate the discharge of debris flow. The volumetric concentration of solid particles of debris flow can also be determined by internal friction angle and inclination [18,19]. Hydrological response analysis on critical precipitation and discharge has thus become more available; meanwhile, predictions on debris flow discharge can feasibly be made. Rainfall, as an important factor formulized as rainfall intensity-duration (I-D) curve for debris flow initiation, has been frequently used [2,20-22]. Rainfall patterns in the Wenchuan earthquake area [21] have shown that the runoff coefficient and peak discharge of an instantaneous heavy rainfall can be 5 to 6 times higher compared than that of a rainfall with uniform intensity [23]. As a potential factor of initiation, the same magnitude of cumulative rainfall may lead to different water discharges when the rainfall pattern is different.

For rainfall pattern estimation, $\operatorname{Huff}(1967,1990)$ [24,25] first divided the precipitation process into four phases, and the National Oceanic and Atmospheric Administration (NOAA ) published the Huff curve in America [26], while Azli et al. (2010) [27] and Domen et al. (2016) [28] studied the temporal characteristics of rainfall around China, Peninsular Malaysia, and Slovenia based on the Huff curve. To reveal how confluence in the catchment changed with different rainfall patterns, the rainfall data used in this paper were gathered from three rainfall stations located on Longmen Mountain (Table 1), and the meteorology of these stations was similar to that of a station in Yuzi River in Yingxiu.

Table 1. Periods during which rainfall data were collected from the website https://rp5.ru.

\begin{tabular}{|c|c|c|c|c|}
\hline Station & WMO_ID ${ }^{a}$ & Location & Altitude & Monitoring Time \\
\hline Dujiangyan & 56,187 & $\begin{array}{l}30^{\circ} 42.00^{\prime} \mathrm{N} \\
103^{\circ} 49.98^{\prime} \mathrm{E}\end{array}$ & $545 \mathrm{~m}$ & 1 January 2013-28 June 2018 \\
\hline Mianyang & 56,196 & $\begin{array}{l}31^{\circ} 28.00^{\prime} \mathrm{N} \\
104^{\circ} 41.00^{\prime} \mathrm{E}\end{array}$ & $522 \mathrm{~m}$ & 1 January 2013-28 June 2018 \\
\hline Ya'an & 56,287 & $\begin{array}{l}29^{\circ} 59.00^{\prime} \mathrm{N} \\
103^{\circ} 00.00^{\prime} \mathrm{N}\end{array}$ & $629 \mathrm{~m}$ & 1 January 2013-28 June 2018 \\
\hline
\end{tabular}

${ }^{a}$ the weather station number of World Meteorological Organization.

This study obtained the rainfall patterns statistically. The corresponding runoff discharge and debris flow discharge were calculated based on distributed hydrological modeling, field surveys, and empirical relationships. Further prediction of rainfall threshold combined with rainfall patterns is presented. A direct survey of the debris flow on 26 July 2016 in Xiongmao Ravine and 165 effective rainfall events were collected. 


\section{Study Area}

On 12 May 2008, Yinxiu, a town in Wenchuan County, located on the fault zone of Longmen Mountain, was hit by a Richter 8.0 earthquake. The straight-line distance of the study area to the epicenter was $32.3 \mathrm{~km}$ (Figure 1). The earthquake heavily damaged the buildings and infrastructure of Wolong town in Wenchuan County, and loosened the mountain surface, resulting in collapse and landslide and providing abundant loose sources for the debris flow.

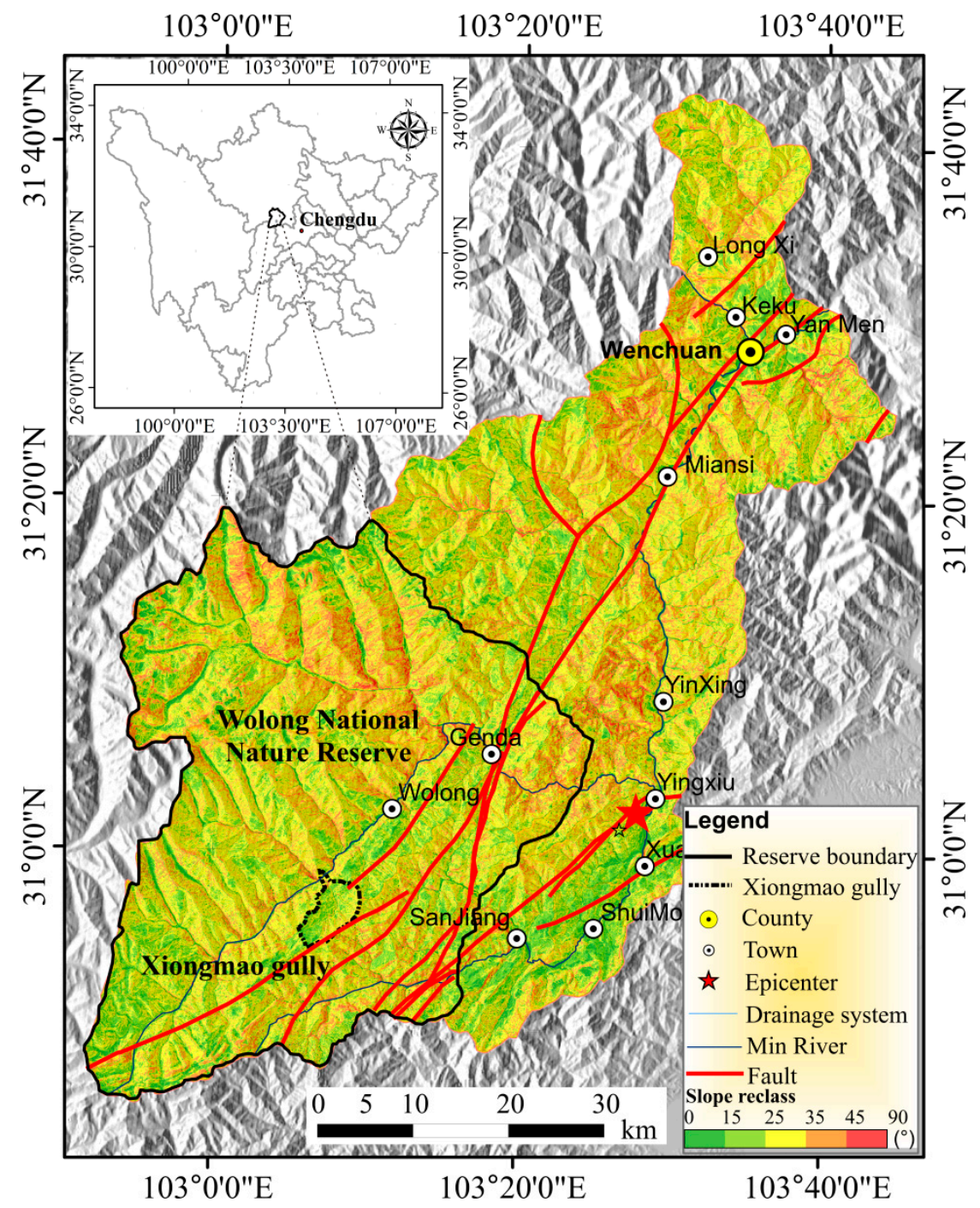

Figure 1. Map of Xiongmao Gully, located in Wolong National Nature Panda Reserve.

Xiongmao Gully, located in the Wolong nature reserves, southwest of Wolong, Wenchuan County, Sichuan Province, is the primary tributary on the right bank of Yuzi river. The average longitudinal length of the gully is $8.8 \mathrm{~km}$, average width is $3.4 \mathrm{~km}$, average longitudinal grade is $169.9 \%$, and the catchment area is $23.6 \mathrm{~km}^{2}$. Additionally, the highest elevation located at the southwest outlet of the gully is $3600 \mathrm{~m}$; the lowest one at the junction between the outlet and Yuzi River is $2105 \mathrm{~m}$. The upstream catchment contains six branches with lengths from 0.9 to $2.4 \mathrm{~km}$ and longitudinal gradients from $15 \%$ to $35 \%$ (Figures 1 and 2). 


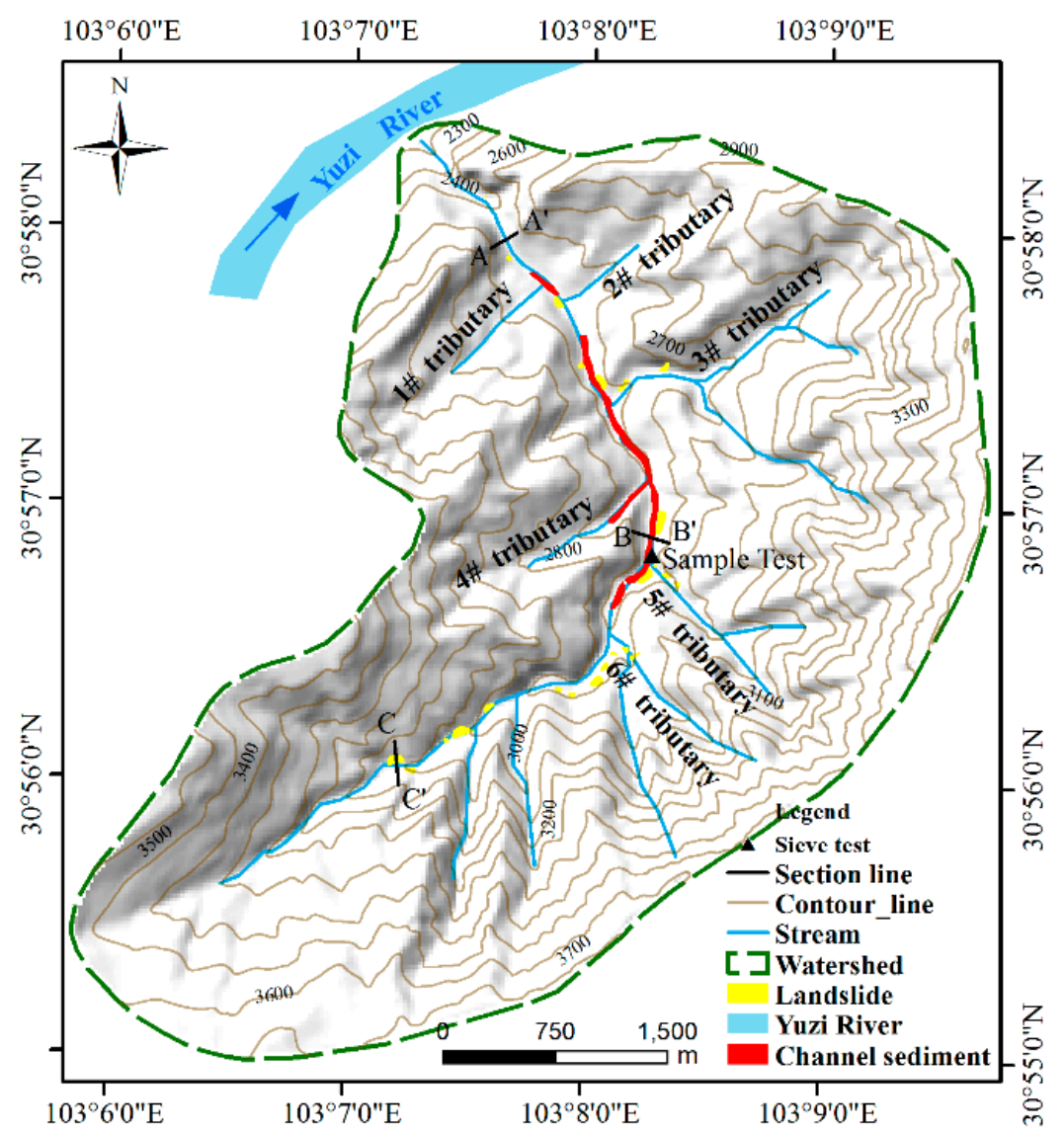

Figure 2. Xiongmao catchment topography and distribution of source materials, in which the black lines are the investigated cross-sections and the black triangles with numbers are the sampling points for the physical tests.

The catchment consists of carbonaceous phyllites, sandy phyllites, slates, and crystalline limestones. The upstream topography of the gully is U-shaped and the vegetation consists mainly of shrubs; the downstream valley is roughly V-shaped, with steep slopes on both sides and well-developed cliffs with gradients of $50^{\circ}-70^{\circ}$. The channel sediment (red areas in Figure 2) in the midstream and collapse accumulation (yellow areas in Figure 2) in the upstream represented the majority of solid material; midstream erosion was located on the red areas, and the main initiation thus occurred along Tributary 6 and Tributary 5.

Debris flows broke out in Xiongmao Gully in 1995, 1998, and May 2004, destroying large areas of agricultural land, but with no casualties reported. The Wenchuan earthquake triggered landslides, producing a large volume of debris deposits in the upstream catchment, providing an abundant source of material for debris flows.

On 26 July 2016, a sudden rainstorm in Wolong with a cumulative rainfall of about $70 \mathrm{~mm}$ between 14:00 and 16:00 increased the water discharge of Yuzi River significantly and, until 16:00, debris flows occurred in Xiongmao Gully, and the debris rushed out and flooded roads, blocking the tributaries in the catchment and Yuzi river, generating tremendous economic damage to the local people and infrastructure (Figure 3). According to the Manual of Floods in Small Watersheds of Sichuan Province, the rainfall within $24 \mathrm{~h}$ at frequencies of $1 \%, 2 \%, 5 \%$, and $10 \%$ in Xiongmao Gully was $211.5 \mathrm{~mm}$, $190.8 \mathrm{~mm}, 162.0 \mathrm{~mm}$, and $139.5 \mathrm{~mm}$, and the rainfall within $6 \mathrm{~h}$ was $127.4 \mathrm{~mm}, 113.7 \mathrm{~mm}, 94.6 \mathrm{~mm}$, and $79.4 \mathrm{~mm}$ respectively. 

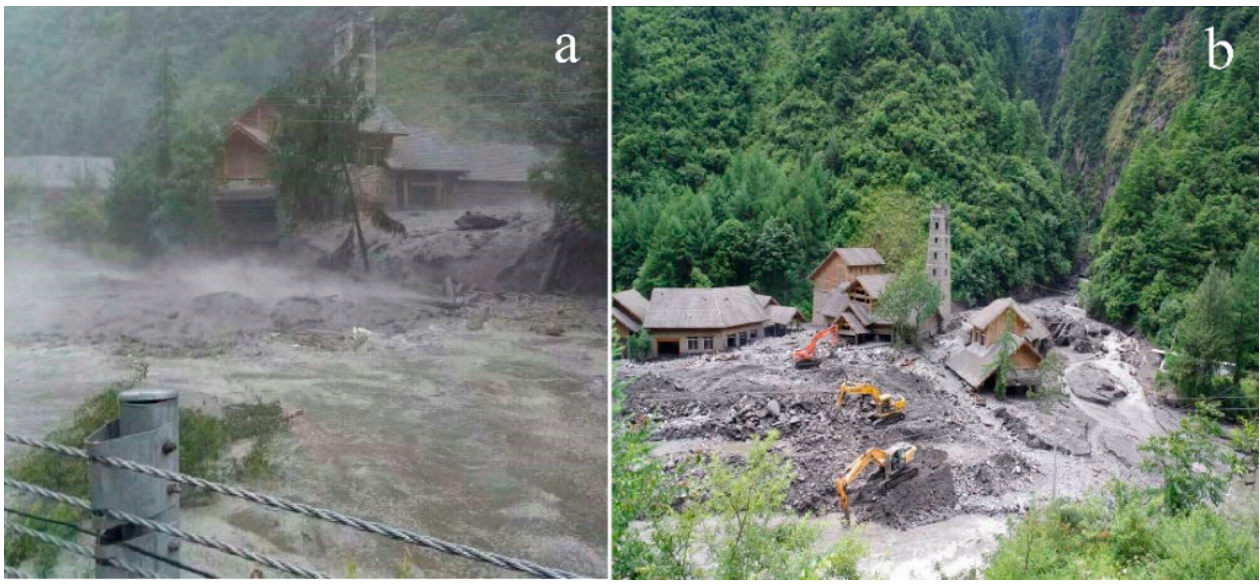

Figure 3. Photo of the scene of the debris flow on 26 July 2016: (a) the outbreak of the debris flow before blocking of the main river; (b) emergency drainage of the debris flow which has dammed the river.

The longitudinal profile of Xiongmao Gully revealed that the whole gully gradually slowed due to the reduced upstream longitudinal gradient from the original $207 \%$ o to $106-144 \%$ o. In particular, the reduced longitudinal gradient of the original area led to the debris being readily deposited and decreased the debris flow velocity. At the downstream transition area, the longitudinal gradient became abrupt, reaching a maximum of $450 \%$, which drove an outrush of debris into Yuzi River (Figure 4).

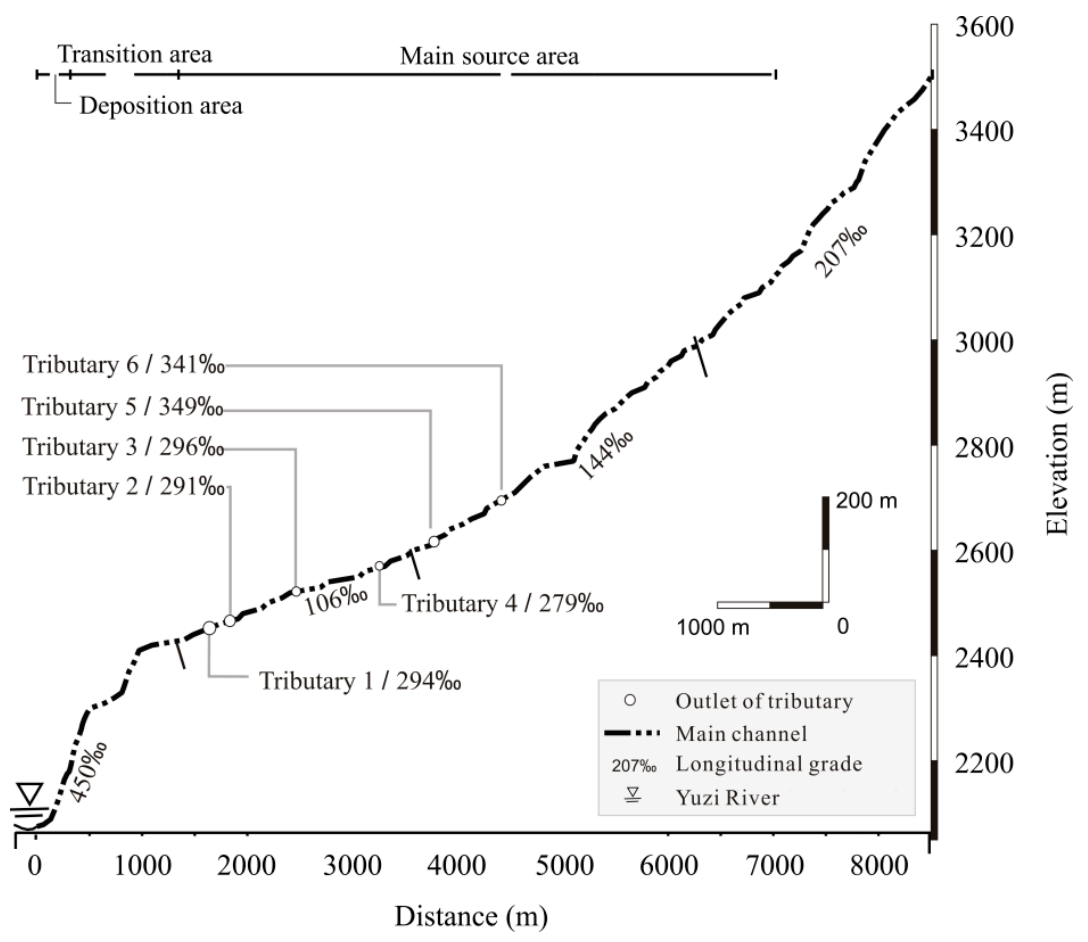

Figure 4. Longitudinal slope line of Xiongmao Gully and longitudinal gradient diagram.

Xiongmao Gully can be divided into source area and transition and accumulation zones. Figure $5 \mathrm{a}, \mathrm{b}$ shows cross-sections of the upper and lower parts of the transition zone, while Figure $5 \mathrm{c}$ shows it through the source area. Photos of the transition zone with a deep gully, the sediment initiation area, and flood flow area are shown in Figure $5 \mathrm{~d}-\mathrm{f}$, respectively. 

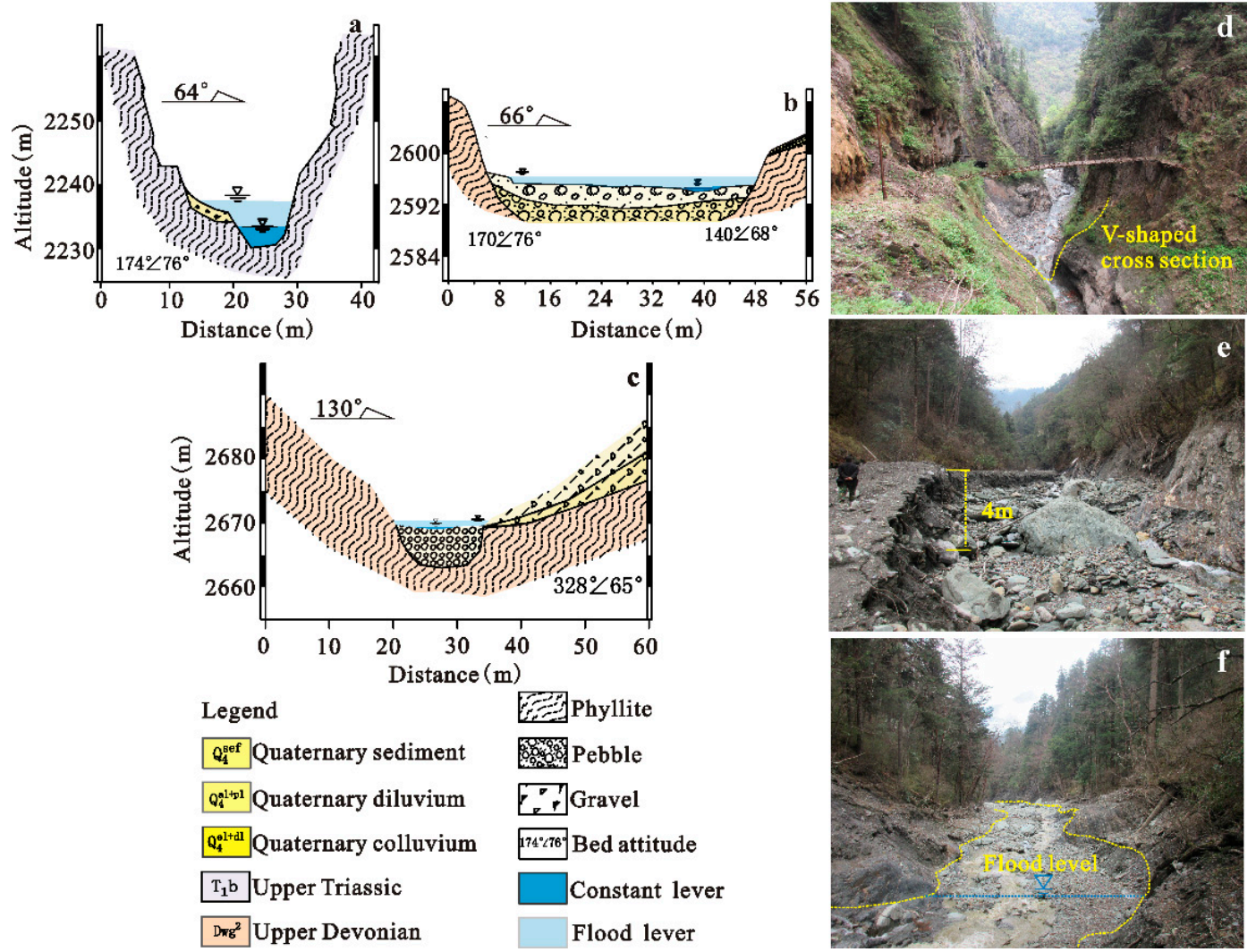

Figure 5. Morphological characteristics of Xiongmao Gully. (a,d) A cross-section of transition zone in which the gully is narrow with exposed bed rock slopes; (b,e) a typical cross-section of the accumulation zone in which the gully is wide with large amounts of solid material; (c) the erosion of slope deposits in the upstream area; (f) nearly no solid materials in the upstream gully.

The gully length of the transition zone is about $0.83 \mathrm{~km}$, with an average longitudinal grade of about $38 \%$ and $45 \%$ at the maximum. In this section, the gully had a V-shape with a width of 3 to $8 \mathrm{~m}$. The channel bed was heavily eroded, and both sides were steep rock slopes without landslides (Figure 5a,d).

The topography of source area was U-shaped, with bank slopes on both sides and abundant unconsolidated material. Most of the slopes were eroded as slightly bank cutting (Figure $5 \mathrm{c}, \mathrm{f}$ ). The upstream valley was covered by a thin layer of weathered deposits and dense vegetation. This region consisted of bare rock slopes and, therefore, could generate a large volume of run-off water for debris flow initiation.

It was known from the source distribution of debris flow in Figure 2 and investigation in Figure 5 that hyper-concentration flow is generated from the upstream of Xiongmao Gully after sufficient confluence flow, and that the channel deposits were eroded by the runoff between Junctions 2 and 3 . Therefore, it was necessary to calculate the critical discharge at this location.

\section{Methods}

Through the laboratory flume experiment relationship, the critical discharge of debris flow initiation in a natural channel was investigated based on source distribution, morphology, topography, and grain composition tests. The rainfall characteristics of the Longmen mountain area were explored using the dynamic $K$-value clustering analysis method. According to HEC-HMS, the hydrological characteristics of the catchment were analyzed at different frequencies and rainfall patterns to predict the critical discharges, providing significant reference for research on rainfall and critical discharge of debris flow in earthquake area. 


\subsection{Rainfall Patterns Statistic}

Wolong County belongs to the climate zone of the Qinghai-Tibet plateau, the weather of which is controlled by the south branch of the westerly jet stream and the southeast monsoon. The area's weather is dry and sunny with less rainfall in winter, while in the summer half-year, under the influence of the humid southeast monsoon, the rainfall is abundant. Table 1 shows the years in which rainfall data were collected from three stations during the period from June to September. These data were used for statistical analyses.

The basic data unit was the hourly rainfall intensity, which was calculated from the cumulative rainfall over time. A series of sequential data obtained from the stations were divided into independent rainfall events using two definitions: inter-event time definition and effective rainfall definition [20,29]. An effective rainfall standard for a rainfall event was amended for the Wenchuan earthquake area [30].

Based on the dimensionless rainfall-duration curve, standardized rainfall profiles (SRP), and Huff curves, a binary shape code (BSC) was established and applied to Calabria (south Italy) to investigate the seasonality of erosivity [31,32]. A total of 165 valid rainfall events were chosen from the rainfall data in this paper, and the rainfall events were divided into four categories of precipitation process to ensure that the properties of each category were similar, according to the dynamic $K$-value clustering method proposed by Yin et al. (2014) [33]. The specific process included rainfall data nondimensionalization, cluster number setting, Euclidean distance calculation, and so on. Each curve corresponded to each rainfall type; the relationship between cumulative rainfall intensity and duration of each rainfall type was then determined.

The rainfall pattern was one of the factors influencing the critical discharge of the catchment, while precipitation evidently affected the critical discharge as well.

\subsection{Hydrological Analysis}

The sub-basin results of Xiongmao Gully were obtained using the Hydrology Model with ARCGIS10.1. It was found that the sub-basins were accurate when the cumulative grid number was 660; furthermore, the above results were applied using HEC-HMS (Figure 6), and the watershed model was built by arranging sub-basins, junctions, reach and sink, etc.

The input settings in HEC-HMS hydrological model included the infiltration property, initial soil water content, and maximum saturate rainfall intensity, which were valued as $6 \%$ and 14 mm by field tests, respectively.

A soil conservation service curve (SCS) was adopted considering the impact of soil property, land use, and soil moisture content at an earlier stage on runoff generation and flow concentration. Regional values depending on geographical and climatic factors were selected in the range of 0.1-0.3 [34]; this value was normally 0.2 in the semi-distributed hydrological model for precisely predicting the runoff $[35,36]$. The curve number $(\mathrm{CN})$ value $[37,38]$ was 85 , based on the general soil type and vegetation cover in the studied area.

SCS unit hydrograph transform was taken as the transform method and used to calculate the peak discharge of unit hydrograph according to precipitation, catchment area, peak, and confluence time [39]. The lag time, combined with the longitudinal grade, runoff length, etc., and the drainage boundary was obtained from ARCGIS. Additionally, a lag time parameter was calculated by lag routing method and kinematic wave routing [40]. 


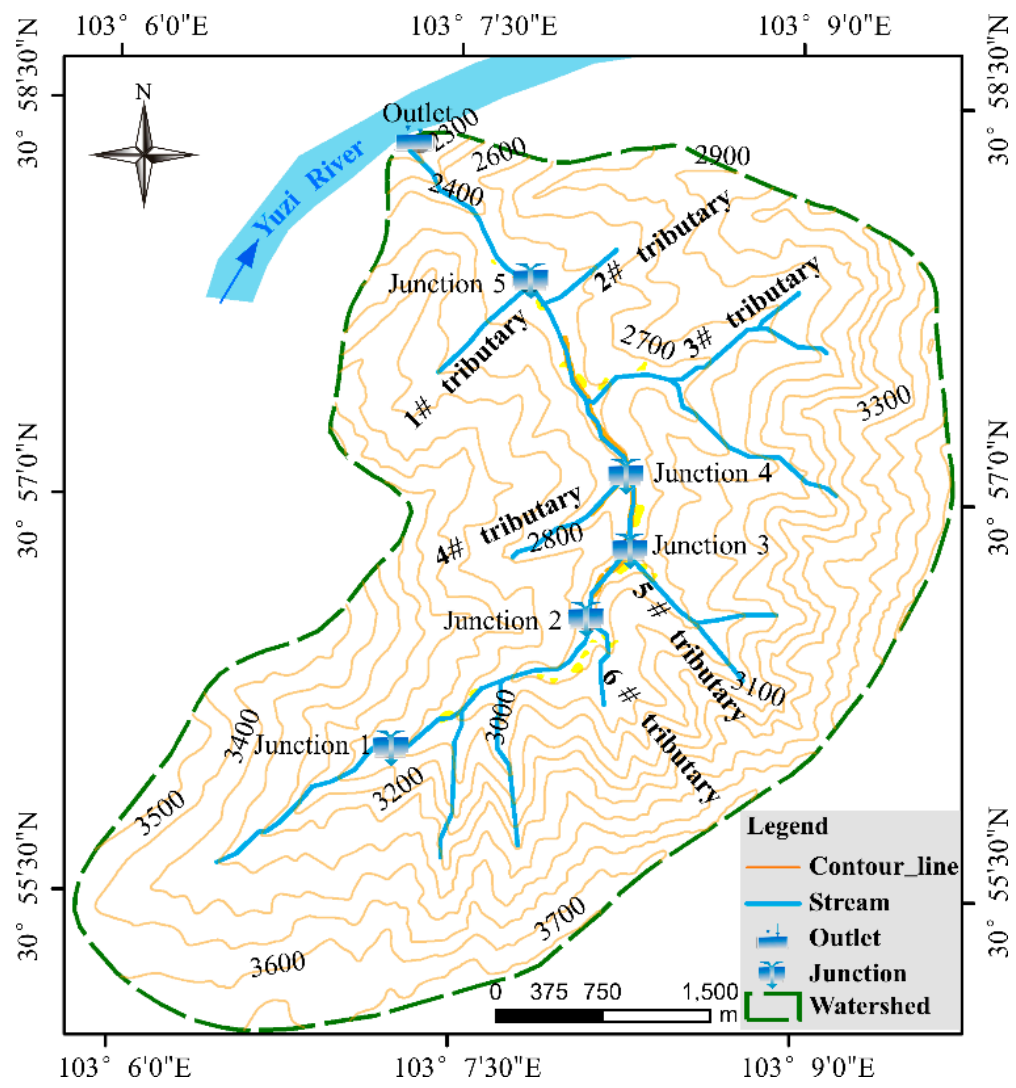

Figure 6. Distribution of junction in the Xiongmao catchment.

Based on the water flow $\left(Q_{p}, \mathrm{~m}^{3} / \mathrm{s}\right)$ at Junction 3 obtained from HEC-HMS, we used the modified flood method [17], considering the volumetric concentration of the solids ( $C_{v}$, dimensionless) and blocking coefficient $\left(D_{c}\right.$, dimensionless) to calculate the debris flow discharge $\left(Q_{c}, \mathrm{~m}^{3} / \mathrm{s}\right)$ :

$$
Q_{c}=D_{c} \cdot Q_{p} /\left(1-C_{v}\right),
$$

where $C_{v}$ represents the solid volume in a unit volume of debris flow, which was calculated by Equation (2).

$$
C_{v}=\gamma-\gamma_{w} /\left(\gamma_{s}-\gamma_{w}\right),
$$

The progress of woody transportation is an important factor of blockage [41] (Rickenmann and Koschni, 2008). The blockage coefficient $\left(D_{c}\right)$ was determined by checking published tables, and the coefficient was normally between 1.0 and 3.0 [42]. Wu et al. (1993) [43] provided a detailed illustration on the blockage coefficient of debris flow, given below.

(1) Slight blockage $\left(D_{c}<1.5\right)$, characterized as a smooth and straight channel, without blockage or steps.

(2) Moderate blockage $\left(1.5 \leq D_{c}<2.5\right)$, characterized as a moderately smooth and straight channel, even width of reach with less blockage and steps.

(3) Severe blockage $\left(D_{c} \geq 2.5\right)$, characterized as a curved channel, uneven width of reach, spreading with blockage and steps.

There were colluvium and decayed trees at the upper catchment of B-B' after the field survey, and the coefficient in this paper was set as 1.5. In Equation (2), $C_{v}$ was the volume concentration of debris flow, $\gamma$ was the specific weight of debris flow, $\gamma_{w}$ was the specific weight of water $\left(0.98 \times 10^{3} \mathrm{~kg} / \mathrm{m}^{3}\right)$, and $\gamma_{s}$ was the specific weight of solid $\left(2.65 \times 10^{3} \mathrm{~kg} / \mathrm{m}^{3}\right)$. 
In order to calculate the specific weight, the equation developed by Yu (2011) [44] was adopted: Coarse particles with sizes were more than $20 \mathrm{~mm}$ were removed from depositions of gullies to calculate debris flow concentration by grain grading analysis, as shown in Equation (3).

$$
\gamma=P_{0.5}^{0.35} P_{2} \gamma_{v}+\gamma_{0}
$$

where $\gamma$ is debris flow concentration $\left(\mathrm{kg} / \mathrm{m}^{3}\right) ; P_{0.5}$ the ratio of fine particles with sizes were less than $0.05 \mathrm{~mm} ; P_{2}$ the ratio of coarse particles with sizes were more than $2 \mathrm{~mm} ; \gamma_{v}$ the minimum concentration of viscous debris flow, equal to $20 \mathrm{KN} / \mathrm{m}^{3}$; and $\gamma_{0}$, the minimum concentration of debris flow, was $1.5 \times 10^{3} \mathrm{~kg} / \mathrm{m}^{3}$.

\subsection{Critical Debris Flow Discharge on Flume Test}

Through a series of laboratory flume experiments, Wang et al. (2017) [9] revealed the relationship between grain size distribution and the hydrodynamic conditions of debris flow. Based on the deposit characteristic of wide grading in the Wenchuan earthquake area, a grain size of 0-60 mm was selected, and the result was as follows:

$$
q_{c}=0.32 d_{84}^{2.5} /\left(\tan ^{2} \theta d_{16} C_{u} C_{c}^{0.4}\right),
$$

For $C_{u}=d_{60} / d_{10}$, and $C_{c}=d_{30}^{2} /\left(d_{60} \times d_{10}\right), \mathrm{d}_{\mathrm{i}}$ was the diameter corresponding to an $i \%$ cumulative distribution of particles smaller than the size; $d_{84}$ was the typical grain size of coarse particles; and $d_{16}$ was that of fine particles.

\section{Results}

Considering that the abundant solid materials on the channel bed were primarily initiated, by contrast, the soil erosion of talus material along channel bank increased the concentration slightly. Thus the position of Junction 3 was set as a typical monitoring cross-section.

\subsection{Rainfall Patterns}

Figure 7 indicates that the period during which the cumulative rainfall increased fastest was in the first period from $0 \%$ to $25 \%$ of the rainfall duration for Pattern I and Pattern II. These periods were defined as first-quartile rainfall according to the Huff curve. Considering the fact that in most cases, debris flows broke out in the middle and later periods of heavy rain events, Pattern III, with durations from $0-50 \%$ of the total duration, was regarded as the second-quartile rainfall; Pattern IV was classified into the same category as Pattern III because the rainfall was concentrated in the duration period of $25-50 \%$.

Through statistical analyses on the rainfall data in the study over the years, the first-quartile and second-quartile rainfalls of Patterns I, II, III, and IV were applied to Xiongmao Gully in order to reveal the hydrological response characteristics under typical rainfall conditions.

As mentioned above, the rainfall intensities within $24 \mathrm{~h}$ at frequencies of $1 \%, 2 \%, 5 \%$, and $10 \%$ in Xiongmao Gully were $211.5 \mathrm{~mm}, 190.8 \mathrm{~mm}, 162.0 \mathrm{~mm}$, and $139.5 \mathrm{~mm}$, respectively. The cumulative rainfall curves of Pattern I, Pattern II, Pattern III, and Pattern IV tended towards $y=x$ graph gradually in Figure 7, and the rainfall intensity concentration degree decreased successively. The typical equations of four cluster centers for the accumulated rainfall $\left(R_{a}\right)$ vs. duration $(t)$ for four types of rainfall pattern were acquired by K-value clustering analysis:

Pattern I, $R_{a}=0.1219 \ln (t)+0.9879, R^{2}=0.9815$

Pattern II, $R_{a}=1.7402 t^{3}-3.984 t^{2}+3.2591 t, R^{2}=0.9978$

Pattern III, $R_{a}=-0.7667 t^{3}+0.1624 t^{2}+1.5868 t, R^{2}=0.9996$

Pattern IV, $R_{a}=-1.8049 t^{3}+2.3173 t^{2}+0.4719 t, R^{2}=0.9997$ 


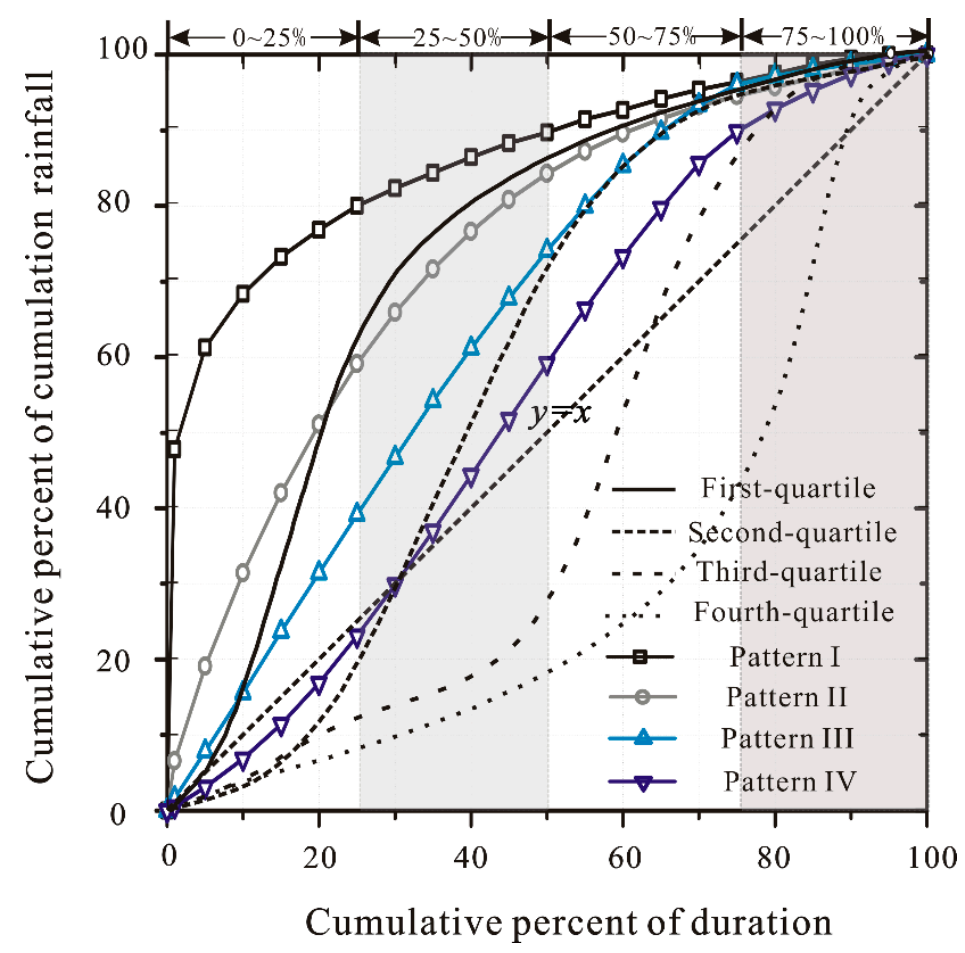

Figure 7. Typical curve of cumulative rainfall duration; first-quartile, second-quartile, third-quartile, and fourth-quartile stand for a 50\% probability level for Huff curve, corresponding to four kinds of curves in the K-value clustering analysis of the data from the observation stations.

\subsection{Runoff Discharge for Various Rainfall Patterns and Frequencies}

The rainfall intensity at any period could be calculated according to the above equations. The precipitation for a certain period and the distribution diagram of hourly rainfall intensity are presented in the upper part of Figure 8 for varying recurrent periods. Additionally, the hourly rainfall intensity distributions for different rainfall patterns are distinguished by different colors, corresponding to the discharge hydrograph of the confluence of Junction 2 and 3 in Figure 6. To present the whole discharge process of a valid rainfall event, the time period was set at $48 \mathrm{~h}$.

Compared to the water volume curve in Xiongmao Gully, the lower part of Figure 8 shows hydrographs at different junctions for different rainfall return periods and rainfall patterns. The rainfall frequencies influenced the flow volumes, and it was found that the peak discharge was influenced by the rainfall patterns. The time at which the peak flows of Pattern I, II, III, and IV emerged were after 480 510 $\mathrm{min}, 780 \sim 810 \mathrm{~min}, 1080 \sim 1110 \mathrm{~min}$, and 1410 1470 min, respectively. However, as shown in Figure $8 \mathrm{~d}$, the peak flow for a frequency of $10 \%$ appeared a little later and lasted for a longer time, indicating that the storage capacity of the vegetation and soil in the catchment retarded and decreased the peak flow.

Pattern I showed larger peak flows at rainfall frequencies of $1 \%$ and $2 \%$, because the high intensity rains for this pattern caused high runoff. The peak flows of Pattern I at the rainfall frequencies of $5 \%$ and $10 \%$ were more or less equal to the peaks of other patterns at the same frequencies, or even less than the runoff peaks of Pattern IV, meaning that larger peaks were more likely to appear in uniform rainfall patterns. 


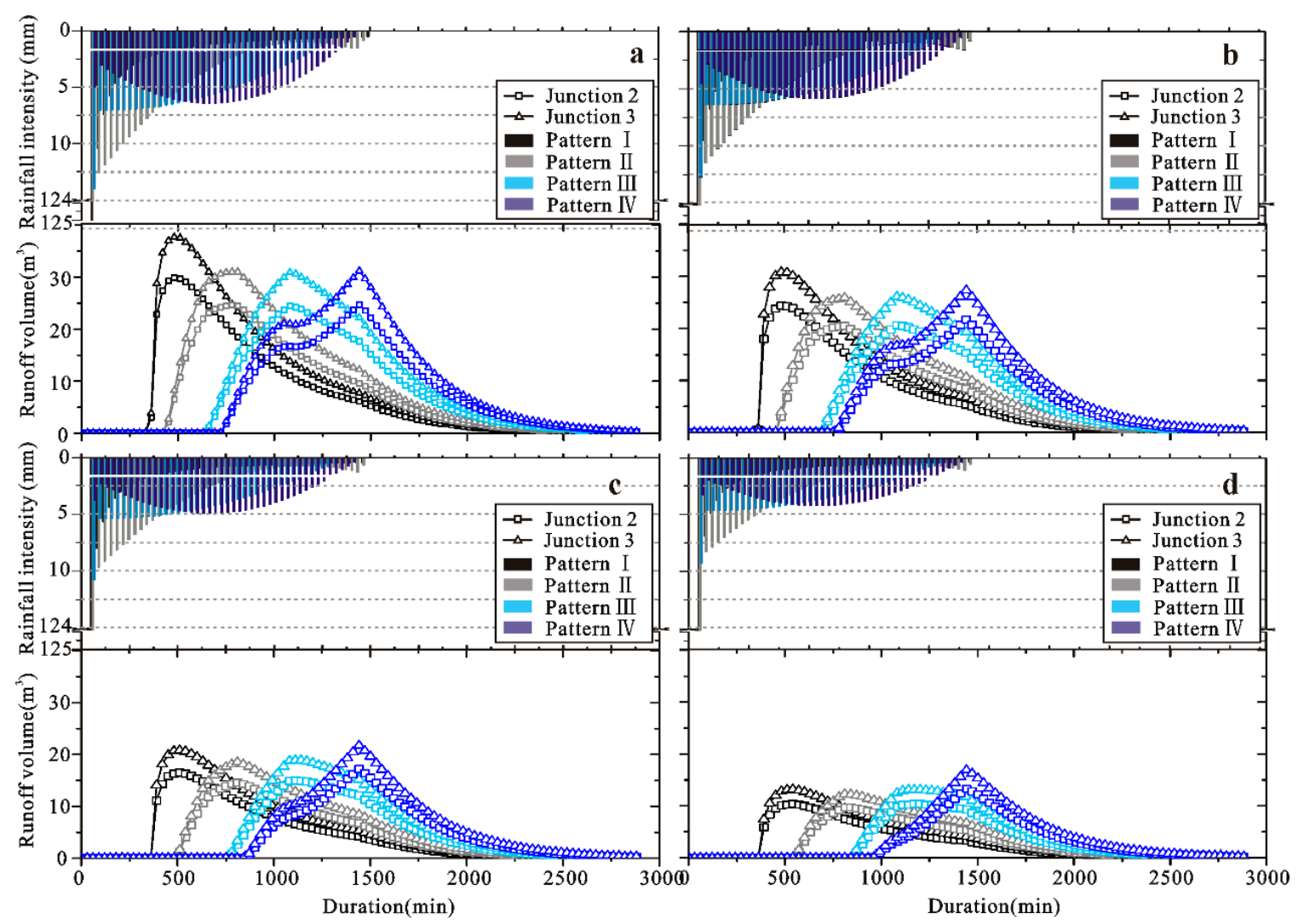

Figure 8. Runoff volumes of Junction 2 and Junction 3. (a-d) The rainfall intensity (upper) and runoff volume (lower) at the frequencies of $1 \%, 2 \%, 5 \%$, and $10 \%$ in Xiongmao Gully.

\subsection{Discharge of Debris Flow and Threshold on 26 July}

Samples were taken from debris flow deposits and colluvial material at a depth of $0-50 \mathrm{~cm}$ for the particle grading test; a grading curve was then acquired from laboratory analyses and grading was done for particle samples smaller than $2 \mathrm{~mm}$ (Figure 9).

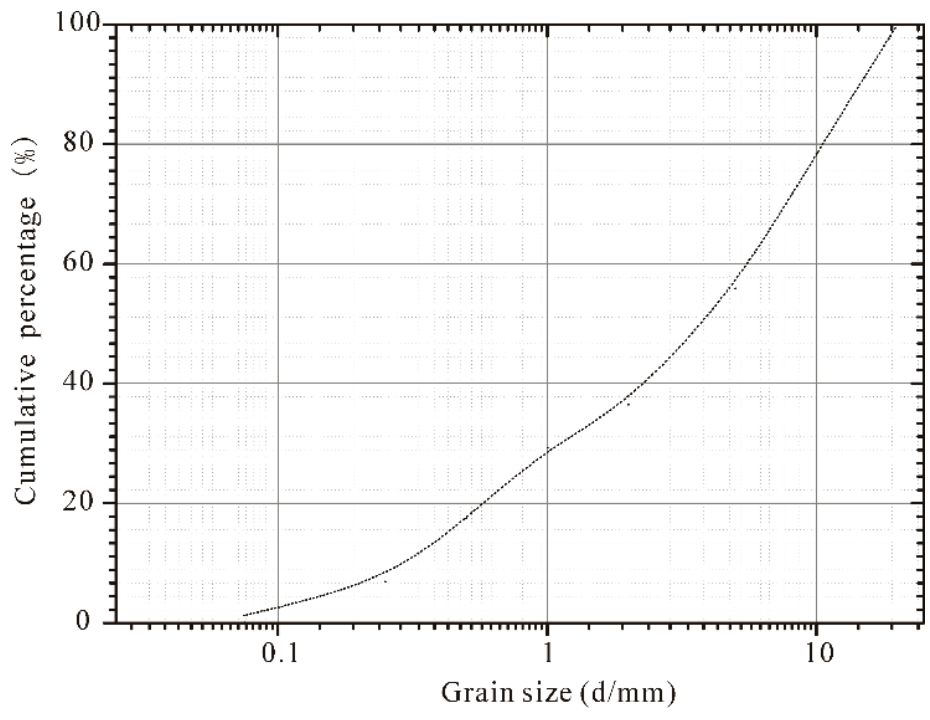

Figure 9. Grading curve of the debris flow deposits in Xiongmao Gully, for which the corresponding location is shown in Figure 2. 
The investigated section of the debris flow in Xiongmao Gully, B-B', was $d_{10}=0.45 \mathrm{~mm}$, $\mathrm{d}_{16}=0.8 \mathrm{~mm}, \mathrm{~d}_{30}=1.24 \mathrm{~mm}, \mathrm{~d}_{60}=18 \mathrm{~mm}, \mathrm{~d}_{84}=36 \mathrm{~mm}, \tan \theta=0.063$; the critical unit discharge of B-B' was $q_{c}=1.206 \mathrm{~m}^{3} / \mathrm{s} \cdot \mathrm{m}$, and the critical discharge was $Q_{c}=43.8 \mathrm{~m}^{3} / \mathrm{s}$.

Referring to Figure 9, the granular size Test $4, \mathrm{P}_{0.05}$ and $\mathrm{P}_{2}$ listed in Table 2, were calculated by Equations (2) and (3); the debris flow density was $\gamma=1.67 \times 10^{3} \mathrm{~kg} / \mathrm{m}^{3}$, the volumetric concentration of the solids $C_{V}=0.42$. The field survey indicated that the maximum flow of debris flow on $26 \mathrm{July}$ 2016 was $Q_{c}=66.7 \mathrm{~m}^{3} / \mathrm{s}$. Table 2 shows the results calculated from Figure 9 and Equation (3).

Table 2. Debris flow parameters at different points of Xiongmao Gully.

\begin{tabular}{ccccc}
\hline Test Location & $\mathbf{P}_{0.05}$ & $\mathbf{P}_{\mathbf{2}}$ & $\gamma_{\mathrm{D}}$ & $\mathrm{C}_{\mathrm{V}}$ \\
\hline Sample Test 4 & $1.3 \%$ & $63.5 \%$ & 1.67 & 0.42 \\
\hline
\end{tabular}

As indicated in the critical discharge analysis, the rainfall conditions led to the outbreak of a debris flow on 26 July 2016; except for the catchment topography and source distribution, the prediction of the rainfall conditions under which debris flow could happen was the aim of this study. The debris flow discharges at cross-section B-B' under rainfall conditions at frequencies of $10 \%$ and $5 \%$, calculated using Equations (1) and (2), are shown in Figure 10, and it can be seen that debris flow was almost impossible in Xiongmao Gully at the frequency of $10 \%$, while debris flow was more likely under the four rainfall patterns at the frequency of $5 \%$.

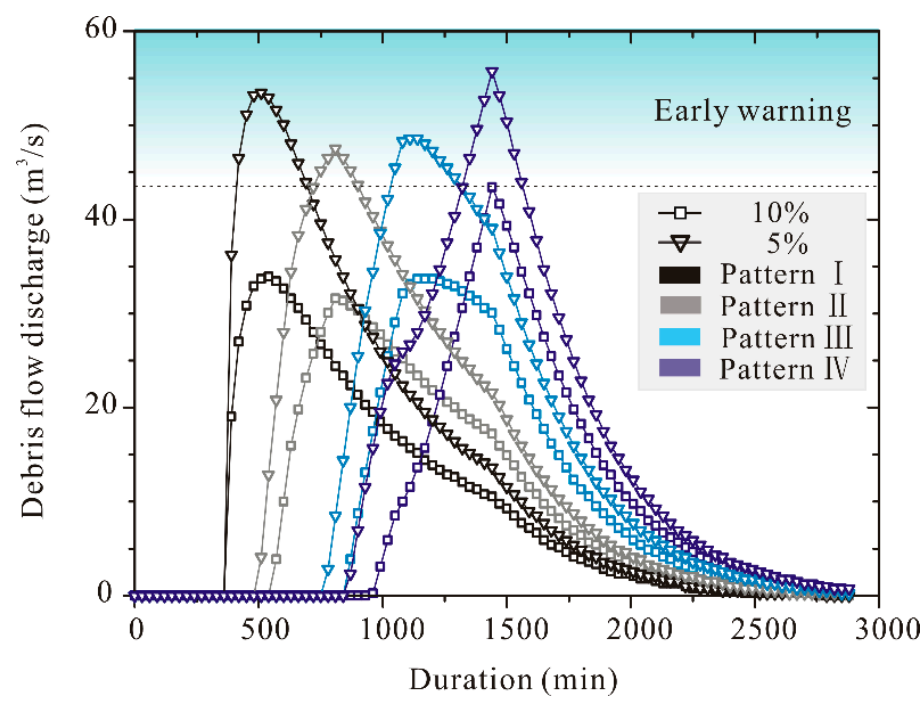

Figure 10. Discharge (under consideration of blocking while $\mathrm{D}_{c}=1.5$ ) of $\mathrm{B}-\mathrm{B}^{\prime}$ under the conditions of different rainfall patterns; square represents the debris flow discharge induced by rainfall at the frequency of $10 \%$; inverted triangle represents the debris flow discharge induced by rainfall at the frequency of $5 \%$; dash/dot line represents the critical discharge on B-B'.

The horizontal dotted line in Figure 10 was the critical discharge at $\mathrm{B}-\mathrm{B}^{\prime}$ corresponding to Junctions 2 and 3, showing four possible rainfall patterns leading to debris flow at the B-B' cross-section and that critical precipitation and duration varied for different rainfall patterns. The rainfall threshold was maximum in $1 \mathrm{~h}$ and $6 \mathrm{~h}$ for Pattern I, and it was the lowest for Pattern IV. 


\section{Discussion}

As shown in Figure 10, the peak discharge and time were affected by various rainfall patterns and frequencies. In addition, the input parameters in HEC-HMS had great influence on the simulated response, so the sensitivity analysis should be taken into consideration. Some confusion emerged on the debris flow discharge based on Equation (1), due to the uncertainty of $\mathrm{D}_{c}$ value in particular. The main topics discussed herein in terms of debris flow discharge include rainfall patterns, parameters, and uncertain values.

\subsection{Statistical Rainfall Patterns}

Huff (1967) [24] divided the curve into first-quartile, second-quartile, third-quartile, and fourth-quartile, and, further, a dimensionless curve was depicted by dividing it into nine probability levels from $10 \%, 20 \%$, through to $90 \%$. According to the above listed rainfall data and K-value clustering analysis, four patterns, cumulative percentage-duration percentage, were categorized as shown in Figure 11. Most studies used the median curve as the typical curve, and 50\% probability level was the most suitable level for the simulation of runoff discharge in practice. Figure 11 depicts the Huff curve at a $50 \%$ probability level, stressed by the varying dot/dash lines.

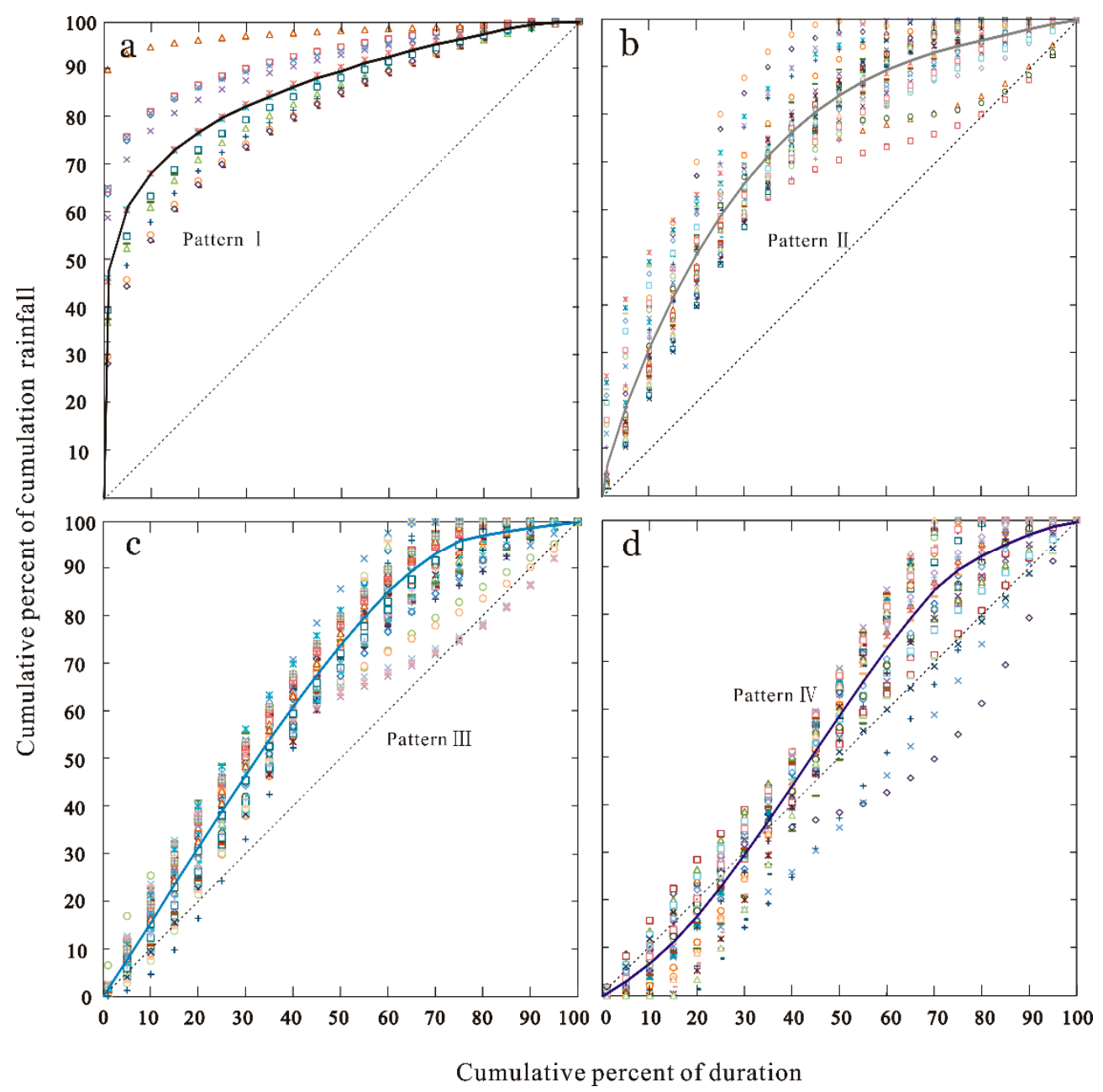

Figure 11. The scatter diagram of rainfall patterns. Four kinds of rainfall patterns including (a) Pattern I, (b) Pattern II, (c) Pattern III, and (d) Pattern IV according to K-value clustering analysis. 
For all of the 165 rainfall events, 14 events belonged to Pattern I (8.48\%), 40 events to Pattern II $(24.24 \%), 71$ events were Pattern III (43.03\%), and the rest were Pattern IV $(24.24 \%)$. The antecedent precipitation dominated in Pattern I. The research results revealed that Pattern I tended towards a temporal rainfall duration of less than $12 \mathrm{~h}$ in general. Pattern II represented rainstorms of temporal rainfall as well.

Zhou et al. (2014) [21] pointed out that the rainfall thresholds varied in the range of $7.8 \sim 38.4 \mathrm{~mm} / \mathrm{h}$ for debris flows which occurred in the Wenchuan earthquake area. For many rainfall events, different rainfall patterns resulted in various discharges and initial water content. Compared with Table 3 , the rainfall threshold of the critical discharge of debris flow varied with rainfall patterns, and the maximum hourly rainfall intensities of Pattern II, Pattern III, and Pattern IV at earlier stage were consistent with the results of the pre-study, while the maximum hourly rainfall intensity was 97.3 $\mathrm{mm} / \mathrm{h}$ for Pattern $\mathrm{I}$, the abrupt heavy rain mode. It was shown from the maximum rainfall threshold at earlier stage of $1 \mathrm{~h}$ and $6 \mathrm{~h}$ that antecedent precipitation made the threshold value decrease compared to heavy rainfall of a short duration (Pattern I).

Table 3. The rainfall threshold at the time of critical discharge on $C-C^{\prime}$.

\begin{tabular}{cccc}
\hline \multirow{2}{*}{ Rainfall Pattern } & Time (min) & $\begin{array}{r}\text { Maximum Precipitation at Earlier Stage (mm) } \\
\mathbf{6 ~ h ~}\end{array}$ \\
\hline Pattern I & 410 & 97.3 & 132.7 \\
Pattern II & 720 & 20.9 & 96.1 \\
Pattern III & 1010 & 10.7 & 64 \\
Pattern IV & 1320 & 9.9 & 53.5 \\
\hline
\end{tabular}

\subsection{Parameter Sensitivity Analysis of HEC-HMS}

For the hydrograph discharge, sampling tests ensured the accuracy of values such as initial storage, maximum surface storage, and $\mathrm{CN}$ values, geographical and climatic factors, potential maximum retention, and maximum vegetation interception proposed in the literature [34,36,38,45]. Based on the method of sensitivity analysis [13], the sensitivity of HEC-HMS simulated flow discharge with four parameters, as presented in Table 4.

Table 4. Parameters sensibility analysis for HEC-HMS simulations of hydrological response.

\begin{tabular}{|c|c|c|c|}
\hline \multirow[t]{2}{*}{ Parameters } & \multicolumn{3}{|c|}{$\begin{array}{l}\text { The Change Ratio of Peak Flow after a Certain Proportion of Single } \\
\text { Increase/Decrease }\end{array}$} \\
\hline & The Basic Condition & Increased by $10 \%$ & Lowered by $10 \%$ \\
\hline $\mathrm{CN}$ & 85 & 0.28 & -0.16 \\
\hline Vegetation interception & $13 \mathrm{~mm}$ & -0.2 & 2 \\
\hline Initial storage & $6 \%$ & 0.01 & -0.01 \\
\hline Surface storage & $14 \mathrm{~mm}$ & -0.02 & 0.02 \\
\hline
\end{tabular}

With the increasing/decreasing parameters from the simulations, the results were simulated as different percentages of discharge relative to the base case, revealing that $\mathrm{CN}$ values plus $10 \%$ or minus $10 \%$ led to a $28 \%$ increase and $16 \%$ decrease of peak discharge, respectively. The valuing of $\mathrm{CN}$ had a significant influence on flow discharge, while other parameters had a weak influence in Xiongmao Gully.

\subsection{Debris Flow Discharge}

For the debris flow discharge, $Q_{p}$ and $C_{v}$ were based on particle size and specific weight of debris flow or water, and Equation (1) was selected to avoid more parameters beyond $D_{c}$. $D_{c}$, valued with the blocking degree of channel, affected discharge significantly. The lowest early warning area when channel blocking (while $\mathrm{D}_{\mathrm{c}}=1.0$ ) was neglected is shown in Figure 12. Compared with Figure 10 
$\left(D_{c}=1.5\right)$, considering the slight blocking, $C-C^{\prime}$ was selected as the analytic crossing section for observable initiation, which could reduce influence on the prediction results for various $D_{c}$ values. All the patterns at $2 \%$ rainfall frequency led to sediment initiation, while discharge may increase along the channel in reality. At the frequency of $5 \%$, shorter durations at $2 \%$ frequency generated larger runoff in the Xiongmao catchment.

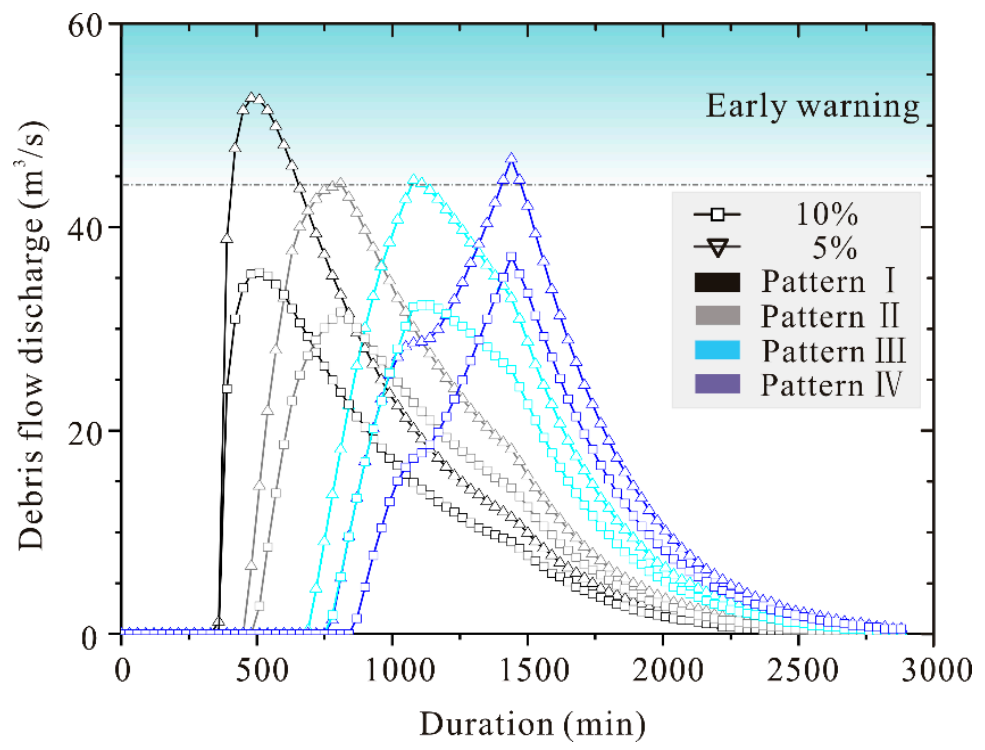

Figure 12. Discharge (no consideration of blocking while $D_{c}=1.0$ ) of $B-B^{\prime}$ under the conditions of different rainfall patterns. Square represents the debris flow discharge induced by rainfall at the frequency of $10 \%$; inverted triangle represents the debris flow discharge induced by rainfall at the frequency of $5 \%$; dash/dot line represents the critical discharge on B-B'.

\section{Conclusions}

It was indicated by field survey that the 2016 outbreak of debris flow in Xiongmao Gully was due to rainfall runoff flooding and erosion of earlier alluvial deposits along the channel banks and bed. Laboratory test relations were used to calculate the debris flow discharge on 26 July 2016, which was lower than the discharge recorded in the field survey. Based on the analyses presented above, the following conclusions were drawn.

Increasing concentrations of runoff and abundant channel sediment incurred debris flow. The gentle gradient and straight channel upstream and midstream ensured that debris flow on Xiongmao Gully developed slightly with increasing concentration and discharge. With a return period of $2 \%$, deposition was initiated primarily in the wide middle of the stream.

The critical discharge at the B-B' cross-section was $43.8 \mathrm{~m}^{3} / \mathrm{s}$, lower than that recorded in the morphological survey on the critical discharge of debris flow $Q_{c}=66.7 \mathrm{~m}^{3} / \mathrm{s}$ (at the frequency of $2 \%$ ).

K-value clustering analysis of the precipitation revealed that there were four rainfall patterns. Pattern I and Pattern II represented cumulative rainfall growing fastest in the duration from $0 \%$ to $25 \%$, characterized by heavy rainfall with short duration, which accounted for $32.7 \%$ of events; the duration period in which rainfall was concentrated most was in the range of $25 \sim 50 \%$ for Pattern III and Pattern $\mathrm{IV}$, in proportion of $67.3 \%$.

Debris flow was more likely to occur under four rainfall patterns at the frequency of $5 \%$ in Xiongmao Gully; however, with the debris material decreasing upstream, a rainfall frequency of $2 \%$ would be required. 
Author Contributions: Conceptualization, L.G. and C.T.; methodology, L.G. and J.X.; Validation, L.G., C.T., J.X. and N.L.; Formal analysis, L.G.; Investigation, L.G., J.X. and N.L.; Resources, C.T.; Data curation, J.X.; writing—original draft preparation, L.G.; Writing—review and editing, C.T.; Visualization, L.G.; Supervision, C.T.; Project administration, C.T.; Funding acquisition, C.T. All authors have read and agreed to the published version of the manuscript.

Funding: This research was funded by the National Key Research and Development Program of China, grant number 2017YFC1501004, the National Natural Science Foundation of China, grant number 41672299 and the State Key Laboratory of Geohazard Prevention and Geoenvironment Protection, grant number SKLGP2017Z002.

Acknowledgments: Theo van Asch helped to improve the language, and his suggestion of the paper is gratefully acknowledged, and Huadi Construction Engineering Limited Company of Sichuan is acknowledged for precious pictures. The authors thank the anonymous reviewers for their helpful suggestions to improve the paper.

Conflicts of Interest: The authors declare no conflict of interest.

\section{References}

1. Coe, J.A.; Glancy, P.A.; Whitney, J.W. Volumetric analysis and hydrologic characterization of a modern debris flow near Yucca Mountain, Nevada. Geomorphology 1997, 20, 11-28. [CrossRef]

2. Coe, J.A.; Kinner, D.A.; Godt, J.W. Initiation conditions for debris flows generated by runoff at Chalk Cliffs, central Colorado. Geomorphology 2008, 96, 270-297. [CrossRef]

3. Godt, J.W.; Coe, J.A. Alpine debris flows triggered by a 28 July 1999 thunderstorm in the central Front Range, Colorado. Geomorphology 2007, 84, 80-97. [CrossRef]

4. Takahashi, T. Mechanical characteristics of debris flow. ASCE J. Hydraul. Div. 1978, 104, 1153-1169.

5. Gregoretti, C. The initiation of debris flow at high slopes: Experimental results. J. Hydraul. Res. 2010, 38, 83-88. [CrossRef]

6. Gregoretti, C.; Fontana, G.D. The triggering of debris flow due to channel-bed failure in some alpine headwater basins of the Dolomites: Analyses of critical runoff. Hydrol. Process. 2008, 22, 2248-2263. [CrossRef]

7. Tognacca, C.; Bezzola, G.R.; Minor, H.E. Threshold criterion for debris-flow initiation due to channel-bed failure. In Proceedings of the 2nd international conference on debris flow, hazards and mitigation, Taipei, Taiwan, 16-18 August 2010; pp. 89-97.

8. Lyu, L.; Wang, Z.; Cui, P.; Xu, M. The role of bank erosion on the initiation and motion of gully debris flows. Geomorphology 2017, 285, 137-151. [CrossRef]

9. Wang, Y.; Cui, P.; Wang, Z.; Liang, S. Threshold criterion for debris flow initiation in seasonal gullies. Int. J. Sediment Res. 2017, 32, 231-239. [CrossRef]

10. Tang, C.; Zhang, S.C. Study progress and expectation for initiation mechanism and prediction of hydraulic-drive debris flows. Adv. Earth Sci. 2008, 23, 787-793.

11. Van Asch, T.; Yu, B.; Hu, W. The Development of a 1-D Integrated Hydro-Mechanical Model Based on Flume Tests to Unravel Different Hydrological Triggering Processes of Debris Flows. Water 2018, 10, 950. [CrossRef]

12. Collischonn, W.; Haas, R.; Andreolli, I.; Tucci, C.E.M. Forecasting River Uruguay flow using rainfall forecasts from a regional weather-prediction model. J. Hydrol. 2005, 305, 87-98. [CrossRef]

13. Ran, Q.H.; Qian, Q.; Li, W.; Fu, X.D.; Yu, X.; Xu, Y.P. Impact of earthquake-induced-landslides on hydrologic response of a steep mountainous catchment: A case study of the Wenchuan earthquake zone. J. Zhejiang Univ. Sci. A 2015, 16, 131-142. [CrossRef]

14. Rickenmann, D. Empirical relationships for debris flows. Nat. Hazards 1999, 19, 47-77. [CrossRef]

15. Chen, N.S.; Yue, Z.Q.; Cui, P.; Li, Z.L. A rational method for estimating maximum discharge of a landslide-induced debris flow: A case study from southwestern China. Geomorphology 2007, 84, 44-58. [CrossRef]

16. Cui, P.; Zhou, G.G.D.; Zhu, X.H.; Zhang, J.Q. Scale amplification of natural debris flows caused by cascading landslide dam failures. Geomorphology 2013, 182, 173-189. [CrossRef]

17. Shen, S.; Xie, X.; Xiang, X.; Li, L.; Gong, C.; Bai, Y.; Xie, X. On Estimation of Debris Flow Discharges. China Railw. Sci. 1993, 14, 80-89. 
18. Takahashi, T. Debris Flow: Mechanics, Prediction and Countermeasures; CRC Press: Boca Raton, FL, USA, 2014. [CrossRef]

19. Wu, Y.H.; Liu, K.F.; Chen, Y.C. Comparison between FLO-2D and Debris-2D on the application of assessment of granular debris flow hazards with case study. J. Mt. Sci. 2013, 10, 293-304. [CrossRef]

20. Jan, C.D.; Lee, M.H. A debris-flow rainfall-based warning model. J. Chin. Soil Water Conserv. 2004, 35, 275-285.

21. Zhou, W.; Tang, C.; Van Asch, T.W.J.; Zhou, C. Rainfall-triggering response patterns of post-seismic debris flows in the Wenchuan earthquake area. Nat. Hazards 2014, 70, 1417-1435. [CrossRef]

22. Guo, X.; Cui, P.; Li, Y.; Ma, L.; Ge, Y.; Mahoney, W.B. Intensity-duration threshold of rainfall-triggered debris flows in the Wenchuan Earthquake affected area, China. Geomorphology 2016, 253, 208-216. [CrossRef]

23. Dunkerley, D. Effects of rainfall intensity fluctuations on infiltration and runoff: Rainfall simulation on dryland soils, Fowlers Gap, Australia. Hydrol. Process. 2012, 26, 2211-2224. [CrossRef]

24. Huff, F.A. Time distribution of rainfall in heavy storms. Water Resour. Res. 1967, 3, 1007-1019. [CrossRef]

25. Huff, F.A. Time Distributions of Heavy Rainstorms in Illinois; Illinois State Water Survey: Champaign, IL, USA, 1990; pp. 1007-1012.

26. Bonnin, G.M.; Martin, D.; Lin, B.; Parzybok, T.; Yekta, M.; Riley, D.; Brewer, D.; Hiner, L. Updates to NOAA Precipitation Frequency Atlases; NOAA: Silver Spring, MD, USA, 2007; pp. 1-10. [CrossRef]

27. Azli, M.; Rao, A.R. Development of Huff curves for Peninsular Malaysia. J. Hydrol. 2010, 388, 77-84. [CrossRef]

28. Dolšak, D.; Bezak, N.; Šraj, M. Temporal characteristics of rainfall events under three climate types in Slovenia. J. Hydrol. 2016, 541, 1395-1405. [CrossRef]

29. Molina-Sanchis, I.; Lázaro, R.; Arnau-Rosalén, E.; Calvo-Cases, A. Rainfall timing and runoff: The influence of the criterion for rain event separation. J. Hydrol. Hydromech. 2016, 64, 226-236. [CrossRef]

30. Zhou, W.; Tang, C.; Van Asch, T.W.J.; Chang, M. A rapid method to identify the potential of debris flow development induced by rainfall in the catchments of the Wenchuan earthquake area. Landslides 2015, 13, 1243-1259. [CrossRef]

31. Terranova, O.G.; Iaquinta, P. Temporal properties of rainfall events in Calabria (southern Italy). Nat. Hazards Earth Syst. Sci. 2011, 11, 751-757. [CrossRef]

32. Terranova, O.; Gariano, S.L. Rainstorms able to induce flash floods in a Mediterranean-climate region (Calabria, southern Italy). Nat. Hazards Earth Syst. Sci. 2014, 14, 2423-2434. [CrossRef]

33. Yin, S.; Wang, Y.; Xie, Y.; Liu, A. Characteristics of intra-storm temporal pattern over China. Adv. Water Sci. 2014, 25, 617-624.

34. Patil, J.P.; Sarangi, A.; Singh, A.K.; Ahmad, T. Evaluation of modified CN methods for watershed runoff estimation using a GIS-based interface. Biosyst. Eng. 2008, 100, 137-146. [CrossRef]

35. Mishra, S.; Singh, V.; Sansalone, J.; Aravamuthan, V. A modified SCS-CN method: Characterization and testing. Water Resour. Manag. 2003, 17,37-68. [CrossRef]

36. Mishra, S.K.; Singh, V.P. Long-term hydrological simulation based on the Soil Conservation Service curve number. Hydrol. Process. 2004, 18, 1291-1313. [CrossRef]

37. USDA. Soil Conservation Service National Engineering Handbook; USDA: Washington, DC, USA, 1993.

38. Fu, S.; Wang, X.; Wang, H.; Wei, X.; Yuan, A. Meathod of determining CN value in the SCS-CN method. Arid Land Geogr. 2012, 35, 415-421.

39. Zhao, J.; Huang, Q.; Hao, P.; Tian, W. Research on Flood Real-Time Forecasting Based on SCS Model. J. Xi'an Univ. Technol. 2013, 29, 386-391.

40. Xie, P.; Ye, S. The research on parameters relationship among of the methods channel flood routing. Int. J. Hydroelectr. Energy 1993, 10, 242-247.

41. Rickenmann, D.; Koschni, A. Sediment loads due to fluvial transport and debris flows during the 2005 flood events in Switzerland. Hydrol. Process. 2010, 24, 993-1007. [CrossRef]

42. Zhuang, J.; Cui, P.; Hu, K.; Chen, X.; Ge, Y. Characteristics of earthquake-triggered landslides and post-earthquake debris flows in Beichuan County. J. Mt. Sci. 2010, 7, 246-254. [CrossRef]

43. Wu, J.S.; Tian, L.Q.; Kang, Z.C. Debris Flow and Its Comprehensive Mitigation; Science Press: Beijing, China, 1993; Volume 135. 
44. Yu, B. Research on prediction of debris flows triggered in channels. Nat. Hazards 2011, 58, 391-406. [CrossRef] 45. Miao, R. Physical Hydrology; Water Resources and Electric Power Press: Beijing, China, 2007.

(C) 2020 by the authors. Licensee MDPI, Basel, Switzerland. This article is an open access article distributed under the terms and conditions of the Creative Commons Attribution (CC BY) license (http://creativecommons.org/licenses/by/4.0/). 